\title{
Enzyme characteristics of aminotransferase FumI of Sphingopyxis sp. MTA144 for deamination of hydrolyzed fumonisin $B_{1}$
}

\author{
Doris Hartinger • Heidi Schwartz • \\ Christian Hametner • Gerd Schatzmayr • \\ Dietmar Haltrich • Wulf-Dieter Moll
}

Received: 2 February 2011 /Revised: 9 March 2011 / Accepted: 12 March 2011 /Published online: 19 April 2011

(C) The Author(s) 2011. This article is published with open access at Springerlink.com

\begin{abstract}
Fumonisins are carcinogenic mycotoxins that are frequently found as natural contaminants in maize from warm climate regions around the world. The aminotransferase FumI is encoded as part of a gene cluster of Sphingopyxis sp. MTA144, which enables this bacterial strain to degrade fumonisin $\mathrm{B}_{1}$ and related fumonisins. FumI catalyzes the deamination of the first intermediate of the catabolic pathway, hydrolyzed fumonisin $\mathrm{B}_{1}$. We used a preparation of purified, His-tagged FumI, produced recombinantly in Escherichia coli in soluble form, for enzyme characterization. The structure of the reaction product was studied by NMR and identified as 2-keto hydrolyzed
\end{abstract}

D. Hartinger $\cdot$ G. Schatzmayr $\cdot$ W.-D. Moll $(\bowtie)$

BIOMIN Research Center,

Technologiezentrum Tulln, Technopark 1,

3430 Tulln, Austria

e-mail: dieter.moll@biomin.net

H. Schwartz

Christian Doppler Laboratory for Mycotoxin Metabolism,

Center for Analytical Chemistry, Department

of Agrobiotechnology IFA-Tulln, University of Natural Resources

and Life Sciences, Vienna,

Konrad Lorenz Strasse 20,

3430 Tulln, Austria

\section{Hametner}

Institute of Applied Synthetic Chemistry, Vienna University

of Technology,

Getreidemarkt 9,

1060 Vienna, Austria

D. Haltrich

Food Biotechnology Laboratory, Department of Food Sciences and Technology, University of Natural Resources

and Life Sciences,

Muthgasse 18,

1190 Vienna, Austria fumonisin $\mathrm{B}_{1}$. Pyruvate was found to be the preferred co-substrate and amino group receptor $\left(K_{\mathrm{M}}=490 \mu \mathrm{M}\right.$ at $10 \mu \mathrm{M}$ hydrolyzed fumonisin $\mathrm{B}_{1}$ ) of FumI, but other $\alpha$-keto acids were also accepted as co-substrates. Addition of the co-enzyme pyridoxal phosphate to the enzyme preparation enhanced activity, and saturation was already reached at the lowest tested concentration of $10 \mu \mathrm{M}$. The enzyme showed activity in the range of $\mathrm{pH} 6$ to 10 with an optimum at $\mathrm{pH} 8.5$, and in the range of $6^{\circ} \mathrm{C}$ to $50^{\circ} \mathrm{C}$ with an optimum at $35^{\circ} \mathrm{C}$. The aminotransferase worked best at low salt concentration. FumI activity could be recovered after preincubation at $\mathrm{pH} 4.0$ or higher, but not lower. The aminotransferase was denatured after preincubation at $60^{\circ} \mathrm{C}$ for $1 \mathrm{~h}$, and the residual activity was also reduced after preincubation at lower temperatures. At optimum conditions, the kinetic parameters $K_{\mathrm{M}}=1.1 \mu \mathrm{M}$ and $k_{\mathrm{cat}}=104 / \mathrm{min}$ were determined with $5 \mathrm{mM}$ pyruvate as co-substrate. Based on the enzyme characteristics, a technological application of FumI, in combination with the fumonisin carboxylesterase FumD for hydrolysis of fumonisins, for deamination and detoxification of hydrolyzed fumonisins seems possible, if the enzyme properties are considered.

Keywords Mycotoxin - Detoxification - Degradation . Kinetics $\cdot$ Feed $\cdot$ Animal

\section{Introduction}

Fumonisins are a group of structurally related mycotoxins produced by several species of Fusarium (Rheeder et al. 2002) as well as by Alternaria alternata (Chen et al. 1992), Aspergillus niger (Frisvad et al. 2007), and Tolypocladium 
species (Mogensen et al. 2011). Fusarium verticillioides may be considered the most important fumonisin producer from the aspect of food and feed safety, as it is an important pathogen of maize in warm climate regions around the world. The fumonisins produced by this fungus were also the first to be isolated (Gelderblom et al. 1988; Bezuidenhout et al. 1988) and thoroughly studied (Marasas 2001). Fumonisin $B_{1}\left(F_{1}\right)$, the most prevalent fumonisin of $F$. verticillioides, can cause equine leukoencephalomalacia (Marasas et al. 1988; Kellerman et al. 1990), porcine pulmonary edema (Harrison et al. 1990; Haschek et al. 2001), liver cancer in rats (Gelderblom et al. 1991), neural tube disorder in mice (Sadler et al. 2002; Gelineau-van Waes et al. 2005), alteration of the immune response in pigs (Taranu et al. 2005), and shows several other toxic effects in laboratory and domestic animals (Voss et al. 2007). Exposure to fumonisins is also associated with cancer and neural tube disorder in humans (Wild and Gong 2010). At the molecular level, fumonisins interfere with sphingolipid metabolism by inhibiting the enzyme ceramide synthase (Wang et al. 1991). The resulting imbalance of sphingolipids, which also have signaling functions as cellular messenger molecules, is responsible for toxic and carcinogenic effects of fumonisins (Merrill et al. 2001; Riley et al. 2001). However, other mechanisms of fumonisin toxicity and carcinogenicity were also proposed, including activation of mitogenactivated protein kinase (Wattenberg et al. 1996), lipid peroxidation (Abel and Gelderblom 1998), and alteration of the biosynthesis of other lipids in addition to the sphingolipids (Gelderblom et al. 2001).

The known fumonisin biodegradation pathways in black yeast strains (Blackwell et al. 1999) and bacteria (Duvick et al. 2003; Heinl et al. 2010) all start with the hydrolytic release of the two tricarballylic acid side chains, catalyzed by a fumonisin carboxylesterase. The second step is deamination of hydrolyzed fumonisin $\mathrm{B}_{1}\left(\mathrm{HFB}_{1}\right)$, either by an amine oxidase in black yeast strains (Blackwell et al. 1999) or an aminotransferase in bacterial strains (Heinl et al. 2010, 2011) (Fig. 1). Enzymatic detoxification of fumonisins may be a suitable approach to increase feed and food safety (Karlovsky 1999). However, it is unclear whether toxicity is sufficiently reduced by enzymatic cleavage of the two tricarballylic acid side chains. Hydrolyzed fumonisins were reported not to have cancerinitiating potency (Gelderblom et al. 1993), to be less hepatotoxic (Howard et al. 2002), less disruptive of sphingolipid metabolism, and not inducing neural tube disorder (Voss et al. 2009) in vivo. Hydrolysis of fumonisins by nixtamalization was reported to reduce, but not eliminate, toxicity (Hendrich et al. 1993; Voss et al. 1996). The in vitro effects of hydrolyzed fumonisins were reported to range from less (Flynn et al. 1997; Norred et al.
1997; Schmelz et al. 1998; van der Westhuizen et al. 1998; Seefelder et al. 2003) to more toxic than those of the intact fumonisins (Gelderblom et al. 1993). The 2-amino group of hydrolyzed fumonisins plays a key role for toxicity, since it can be acylated both in vitro (Humpf et al. 1998) and in vivo (Seiferlein et al. 2007), and the $N$-acyl-metabolites are even more cytotoxic than $\mathrm{FB}_{1}$ (Humpf et al. 1998). In summary, deamination in addition to removal of the side chains may be necessary for complete fumonisin detoxification. Since the bacterial aminotransferases, contrary to the black yeast amine oxidases, do not require molecular oxygen for activity, they may be more suitable for applications in anaerobic environments, for instance as feed or food enzymes for detoxification directly in the intestinal tract of animals or humans. Another possible application would be in ethanol fermentation of maize mash, where fumonisins normally accumulate in the distillers dried grains and solubles, which are subsequently used as animal feed.

We have previously cloned the fumI gene of Sphingopyxis sp. MTA144, which catalyzes deamination of $\mathrm{HFB}_{1}$ (Heinl et al. 2010), expressed the gene in E. coli and purified the enzyme (Hartinger et al. 2010). Here, we report the characterization of the enzyme together with its kinetic parameters as a starting point for evaluation of the application potential of the enzyme.

\section{Materials and methods}

\section{Chemicals}

$\mathrm{FB}_{1}$ and ${ }^{13} \mathrm{C}-\mathrm{FB}_{1}$ were obtained from Biopure Referenzsubstanzen $\mathrm{GmbH}$ (Tulln, Austria). $\mathrm{HFB}_{1}$ was prepared by complete hydrolysis of $\mathrm{FB}_{1}$ with purified recombinant carboxylesterase FumD (Heinl et al. 2010). All other chemicals were purchased from Sigma (St. Louis, MO, USA) or Sigma-Aldrich (Steinheim, Germany). Water was purified by reverse osmosis in an arium ${ }^{\circledR}$ RO 61316 system (Sartorius Stedim Biotech GmbH, Göttingen, Germany).

Recombinant enzyme production and purification

Construction of the expression vector pET-30a-AT144HIS, gene expression in E. coli ArcticExpress(DE3), and purification of the 6xHis-tagged recombinant aminotransferase FumI by immobilized nickel affinity chromatography were previously described (Hartinger et al. 2010). The recombinant enzyme FumI-HIS comprises the FumI sequence (GenBank ACS27061) with a C-terminal extension of ASSVD KLAAALEHHHHHH. The calculated molecular mass is 48,271.5 Da. Preparations of FumI-HIS were stored at $-20^{\circ} \mathrm{C}$ after addition of glycerol to $25 \%$. 
Fig. 1 Initial steps of fumonisin $\mathrm{B}_{1}$-degradation pathway of Sphingopyxis sp.

MTA144: FB 1 (2-amino-12,16dimethyl-3,5,10-trihydroxy-14,15propan-1,2,3-tricarboxyicosane) is substrate of the fumonisin carboxylesterase FumD, which catalyzes hydrolytic cleavage of both tricarballylic acid (TCA) chains off the core chain to produce $\mathrm{HFB}_{1}$ (2amino-12,16-dimethylicosane3,5,10,14,15-pentol) and tricarballylic acid $(1,2,3-$ propanetricarboxylic acid). Aminotransferase FumI transfers the 2-amino group from $\mathrm{HFB}_{1}$ to pyruvate, producing 2-keto-HFB $(3,5,10,14,15$-pentahydroxy12,16-dimethylicosane-2-one) and alanine

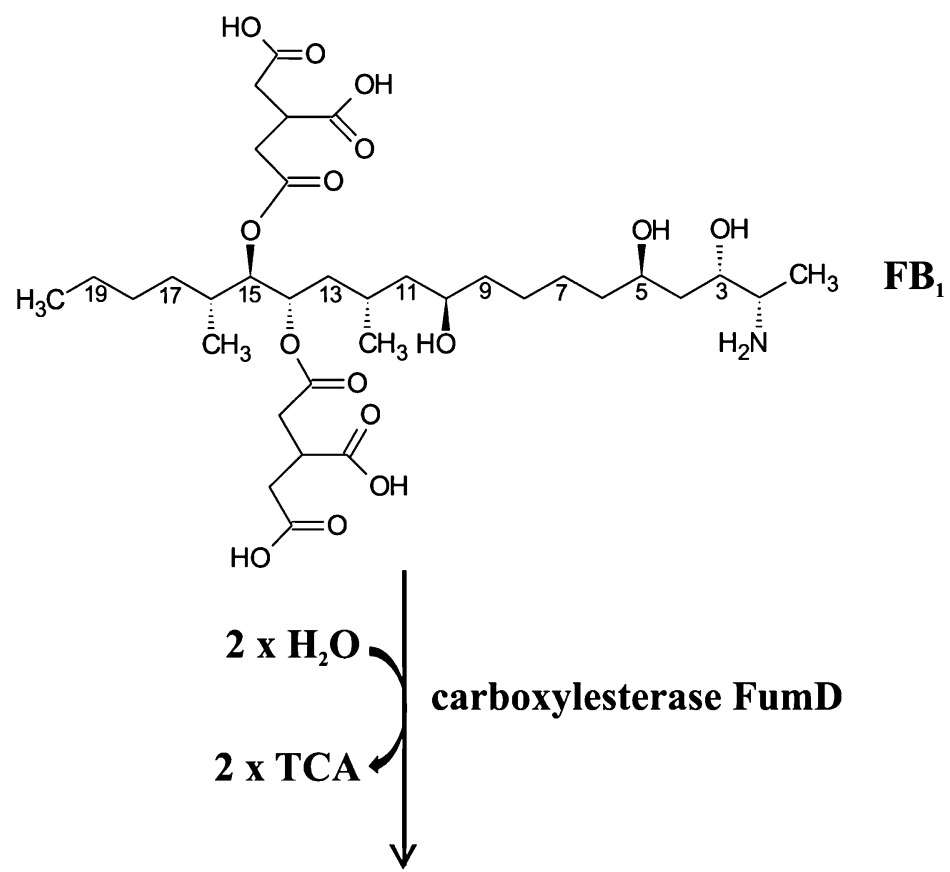<smiles>CCCC=C(C)[C@H](O)C(O)C[C@@H](C)C[C@H](O)CCCC[C@@H](O)C[C@@H](O)C(C)N</smiles>

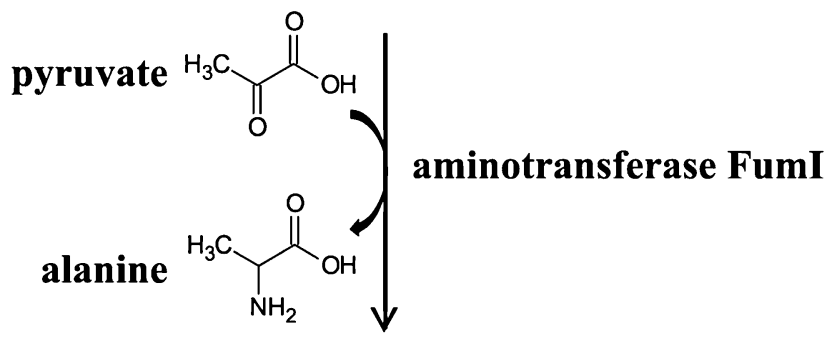

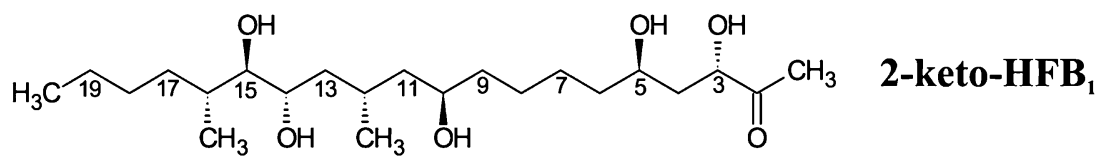

Enzyme activity assays

Possible co-substrates of the aminotransferase were tested in a reaction system containing $94 \mathrm{ng} / \mathrm{ml}$ FumI-HIS in $20 \mathrm{mM}$ Tris- $\mathrm{HCl} \mathrm{pH}$ 7.4, $50 \mathrm{mM} \mathrm{NaCl}, 2 \mathrm{mM} \mathrm{CaCl}_{2}$, $20 \mu \mathrm{M}$ pyridoxal phosphate (PLP), and $0.1 \mathrm{mg} / \mathrm{ml}$ bovine serum albumin (BSA). $\mathrm{HFB}_{1}$ as the substrate was employed at a concentration of $15 \mu \mathrm{M}$, and no co-substrate or $15 \mu \mathrm{M}$ or $3 \mathrm{mM}$ of the $\alpha$-keto acids pyruvate, $\alpha$-ketobutyrate, $\alpha$ ketoglutarate, glyoxylate, or oxaloacetate, respectively, were added. Samples of $200 \mu \mathrm{l}$ were taken immediately after addition of the enzyme to the reaction mixture $(t=0 \mathrm{~h})$, as well as after $0.5,1$, and $3 \mathrm{~h}$ of incubation in a water bath at $25^{\circ} \mathrm{C}$. For correlation of enzyme activity with pyruvate and oxaloacetate concentration, the assay was performed as above except with $10 \mu \mathrm{M} \mathrm{HFB}$, and co-substrate concentrations were varied from 0.01 to $100 \mathrm{mM}$. Aminotransferase activity was determined by calculating the slope of the initial, linear reaction rates in $\Delta \mu \mathrm{mol} \mathrm{HFB}_{1}$ per liter per minute. Oxaloacetate was dissolved directly before use to avoid decarboxylation. To test the need for addition of PLP, the assay was performed as above with $15 \mu \mathrm{M} \mathrm{HFB}_{1}$ and PLP concentrations ranging from 0 to $400 \mu \mathrm{M}$. The effect of salt on enzyme activity was tested by using $20 \mathrm{mM}$ Tris$\mathrm{HCl} \mathrm{pH} 8.0$ buffers with $1,000 \mathrm{mM}, 100 \mathrm{mM}, 10 \mathrm{mM}$ $\mathrm{NaCl}$, or without added $\mathrm{NaCl}$, Teorell-Stenhagen buffer 
pH 8.0 (Teorell and Stenhagen 1938), or $100 \mathrm{mM}$ potassium phosphate buffer, all with $20 \mu \mathrm{M}$ PLP, $0.1 \mathrm{mg} / \mathrm{ml}$ BSA, $3 \mathrm{mM}$ pyruvate, and $15 \mu \mathrm{M} \mathrm{HFB}{ }_{1}$.

The optimum $\mathrm{pH}$ for enzyme activity was determined by setting Teorell-Stenhagen buffer to $\mathrm{pH}$ values ranging from $\mathrm{pH} 1.8$ to 11.5 at $22^{\circ} \mathrm{C}$ (Teorell and Stenhagen 1938). The assay was performed using $67 \mathrm{ng} / \mathrm{ml}$ FumI-HIS, $10 \mu \mathrm{M}$ $\mathrm{HFB}_{1}, 20 \mu \mathrm{M}$ PLP, $0.1 \mathrm{mg} / \mathrm{ml} \mathrm{BSA}$, and $5 \mathrm{mM}$ pyruvate at $25^{\circ} \mathrm{C}$. Samples were taken before addition of enzyme and after 15, 30, 45, 60, 120, and $240 \mathrm{~min}$. Enzyme activities were calculated from early time points, where reaction rates were linear, and are expressed as $\mu \mathrm{M}$ 2-keto-HFB ${ }_{1}$ formed per minute. The optimum temperature for enzyme activity was determined by using the same conditions as for the $\mathrm{pH}$ dependence, with the buffer set to $\mathrm{pH} 8.0$ at $22^{\circ} \mathrm{C}$, and incubation temperatures in water baths ranging from $6^{\circ} \mathrm{C}$ to $50^{\circ} \mathrm{C}$. Reaction mixtures were temperature-equilibrated for 30 min before addition of enzyme.

To determine $\mathrm{pH}$ stability of FumI-HIS, the TeorellStenhagen buffer was set to $\mathrm{pH}$ values between $\mathrm{pH} 1.1$ and 10.7 , and $14 \mu \mathrm{g} / \mathrm{ml}$ of enzyme was incubated in these buffers at $35^{\circ} \mathrm{C}$ for $1 \mathrm{~h}$. The residual enzyme activity was determined in the same buffer at $\mathrm{pH} 7.8$ after dilution of FumI-HIS to $50 \mathrm{ng} / \mathrm{ml}$, using $15 \mu \mathrm{M} \mathrm{HFB}, 20 \mu \mathrm{M}$ PLP, $0.1 \mathrm{mg} / \mathrm{ml} \mathrm{BSA}$, and $5 \mathrm{mM}$ pyruvate. Samples were taken, and reaction rates were determined as for the correlation of activity with $\mathrm{pH}$ and temperature. The thermal stability of FumI-HIS was determined by incubating $14 \mu \mathrm{g} / \mathrm{ml}$ of enzyme in Teorell-Stenhagen buffer, set to $\mathrm{pH} 8.0$ at $22^{\circ} \mathrm{C}$, for $1 \mathrm{~h}$ in water baths at temperatures ranging from $7^{\circ} \mathrm{C}$ to $60^{\circ} \mathrm{C}$. Residual enzyme activity was measured at $35^{\circ} \mathrm{C}$ after dilution in the same buffer with final concentrations of FumI-HIS, $\mathrm{HFB}_{1}$, PLP, BSA, and pyruvate as described for $\mathrm{pH}$ stability. Samples were taken, and reaction rates were calculated as for the determination of optimum $\mathrm{pH}$ and temperature.

Enzyme kinetics were determined by incubating $10 \mathrm{ng} / \mathrm{ml}$ FumI-HIS at $35^{\circ} \mathrm{C}$ in $20 \mathrm{mM}$ Tris- $\mathrm{HCl}$ $\mathrm{pH}$ 8.0, $20 \mu \mathrm{M}$ PLP, $0.1 \mathrm{mg} / \mathrm{ml} \mathrm{BSA}$, and $5 \mathrm{mM}$ pyruvate, while the concentration of $\mathrm{HFB}_{1}$ was varied from 0.1 to $100 \mu \mathrm{M}$. Samples were taken, and reaction rates were determined as above.

\section{Liquid chromatography-mass spectrometry}

Samples taken from enzyme assays were inactivated at $99^{\circ} \mathrm{C}$ for $10 \mathrm{~min}$ and stored frozen. After thawing, mixing, and centrifugation, aliquots of samples containing nominally $0.2 \mathrm{nmol} \mathrm{HFB}_{1}$, but no more than $100 \mu \mathrm{l}$, were dried at $50^{\circ} \mathrm{C}$ under a stream of nitrogen and dissolved in $200 \mu \mathrm{l}$ solvent with ${ }^{13} \mathrm{C}-\mathrm{FB}_{1}$ as internal standard. Thus, the final nominal $\mathrm{HFB}_{1}$ concentration for analysis was $1 \mu \mathrm{M}$, or less if the original concentration was less than $2 \mu \mathrm{M}$. All samples were analyzed using the previously described instrumental setup and method (Heinl et al. 2010), to which 2-keto-HFB has been integrated (Hartinger et al. 2010).

Preparative isolation of 2-keto- $\mathrm{HFB}_{1}$ and structure determination by NMR

FumI-HIS was produced in E. coli ArcticExpress (DE3) as previously described (Hartinger et al. 2010). Biomass was resuspended in $1 / 100$ of the culture volume, homogenized in a French Press, and $1.2 \mathrm{ml}$ of the clarified lysate was added to $4.05 \mathrm{mg} \mathrm{HFB}_{1}$ in $25 \mathrm{ml}$ buffer $(20 \mathrm{mM}$ Tris- $\mathrm{HCl}$ $\mathrm{pH} 8.0,6.6 \mathrm{mM}$ pyruvate, $30 \mu \mathrm{M}$ PLP, and $0.1 \mathrm{mg} / \mathrm{ml}$ BSA). After incubation at $30^{\circ} \mathrm{C}$, complete deamination of $\mathrm{HFB}_{1}$ was confirmed by liquid chromatography-mass spectrometry (LC-MS). The reaction mixture was centrifuged, lyophilized, and dissolved in $6 \mathrm{ml}$ of $40 \%$ acetonitrile in water $(v / v)$. After centrifugation, $600-\mu 1$ portions were separated on a preparative Agilent 1100 HPLC system (Agilent, Waldbronn, Germany) consisting of a G1361A pump, a G2260A autosampler, an adjustable flow splitter (Analytical Scientific Instruments, CA, USA), an evaporative light-scattering detector (SEDEX LT-ELSD Model 85, Sedere, Alfortville, France), a G1365B multiwavelength detector, and a G1364B fraction collector. A Gemini-NX C18 column $(150 \times 21.2 \mathrm{~mm}, 5-\mu \mathrm{m}$ particle size, $110-\AA ̊$ pore size; Phenomenex, Aschaffenburg, Germany) protected by a Gemini C18 pre-column $(15 \times 21.2 \mathrm{~mm})$ was operated at a flow rate of $16 \mathrm{ml} / \mathrm{min}$ using gradient elution. Mobile phase A, consisting of acetonitrile/ $\mathrm{H}_{2} \mathrm{O}(10: 90, v / v)$, was degassed by membrane filtration. Acetonitrile was used as mobile phase $\mathrm{B}$. The gradient was as follows: $0-0.2 \mathrm{~min}$ : $0 \% \mathrm{~B}, 0.2-5 \mathrm{~min}$ : linear increase to $95 \% \mathrm{~B}, 5-6.4 \mathrm{~min}$ : isocratic elution at $95 \% \mathrm{~B}, 6.4-6.5 \mathrm{~min}$ : linear decrease to $0 \% \mathrm{~B}, 6.5-9.5 \mathrm{~min}$ : re-equilibration at $0 \% \mathrm{~B}$. The column effluent was split 1:70, one part moving into the evaporative light-scattering detector and the main part passing through the multivariate wavelength detector to the fraction collector. The 2-keto-HFB 1 eluted between 4.85 and $5.7 \mathrm{~min}$ and fractions were collected in that time window. The combined fractions were evaporated to dryness on a rotary evaporator, dissolved in $7 \mathrm{ml}$ of ethyl acetate, and transferred into an 8-ml screw cap vial; the ethyl acetate solution was evaporated to dryness under a stream of nitrogen at $50^{\circ} \mathrm{C}$. The 2 -keto-HFB ${ }_{1}$, a viscous, clear, and colorless oily substance, was stored at $4^{\circ} \mathrm{C}$ until NMR analysis.

${ }^{1} \mathrm{H}$ - and ${ }^{13} \mathrm{C}$-NMR spectra were obtained from $\mathrm{CD}_{3} \mathrm{CN}$ solutions using an Avance DRX-400 FT-NMR spectrometer (Bruker BioSpin, Rheinstetten, Germany), operating at $400.13 \mathrm{MHz}$ for ${ }^{1} \mathrm{H}$ and $100.62 \mathrm{MHz}$ for ${ }^{13} \mathrm{C}$, at $295 \mathrm{~K}$ using a 5 -mm inverse broadband $Z$-gradient probe head. Data were recorded and evaluated using TOPSPIN 1.3 
software (Bruker Biospin). All pulse programs were taken from the Bruker software library. Chemical shifts were established on the basis of residual solvent resonances.

\section{Results}

\section{Biochemical characterization of FumI-HIS}

Clarified cell lysates of E. coli overexpressing the fumI gene were previously used to obtain preliminary information, namely that $\mathrm{HFB}_{1}$ is a substrate and that an $\alpha$-keto acid such as pyruvate is required as co-substrate for the activity of the aminotransferase FumI (Heinl et al. 2010). The detailed biochemical characterization reported here was made using FumI-HIS, which was prepared and purified to electrophoretic homogeneity as described before (Hartinger et al. 2010). This enzyme preparation was found to be stable for several months when stored in $25 \%$ glycerol at $-20^{\circ} \mathrm{C}$. Clarified cell lysates of E. coli ArcticExpress (DE3) producing FumI and FumI-HIS from the same expression vector $\mathrm{pET}-30 \mathrm{a}$ under identical conditions showed a very similar $\mathrm{HFB}_{1}$ deamination activity, indicating that the Histag does not affect the enzymatic activity.

The $\alpha$-keto acids pyruvate, $\alpha$-ketobutyrate, $\alpha$-ketoglutarate, glyoxylate, and oxaloacetate were tested as potential co-substrates for aminotransferase FumI (Fig. 2). No deamination of $\mathrm{HFB}_{1}$ was detectable when no co-substrate was added or in the presence of $\alpha$-ketoglutarate, while pyruvate, oxaloacetate, glyoxylate, and $\alpha$-ketobutyrate, when included at $3 \mathrm{mM}$ concentration, supported the reaction, with $\mathrm{HFB}_{1}$ deamination efficiency decreasing in this order. When tested

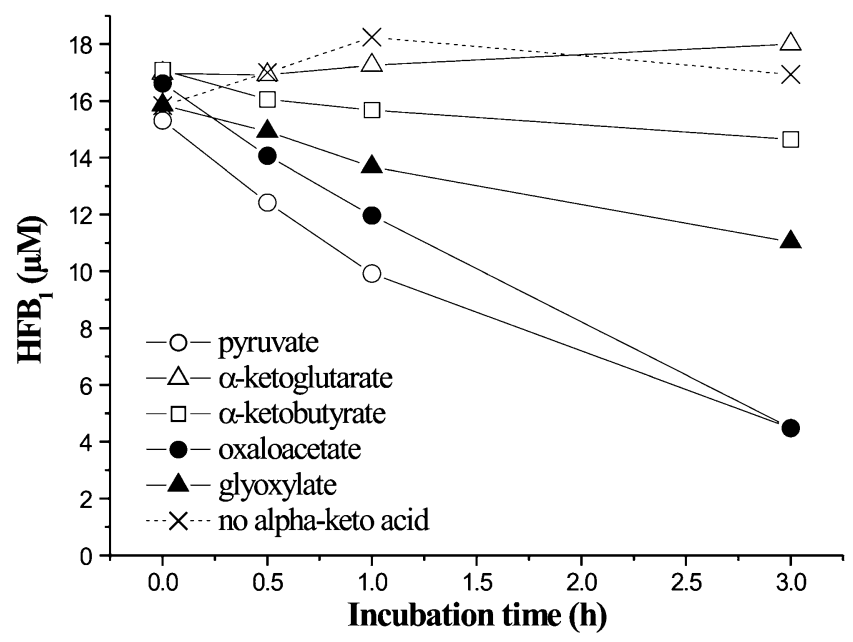

Fig. 2 Comparison of $\mathrm{HFB}_{1}$ deamination activity of FumI-HIS with five different $\alpha$-keto acids as co-substrate. The reactions were incubated in $20 \mathrm{mM}$ Tris- $\mathrm{HCl}$ buffer $(\mathrm{pH} 7.4)$ at $25^{\circ} \mathrm{C}$ with $94 \mathrm{ng} / \mathrm{ml}$ FumI and $3 \mathrm{mM} \alpha$-keto acid with $10 \mu \mathrm{M} \mathrm{HFB}_{1}$, the enzyme showed maximal activity at $10 \mathrm{mM}$ pyruvate, and the $K_{\mathrm{M}}$ for pyruvate was $490 \mu \mathrm{M}$. Deamination activity was significantly reduced when the concentration of the co-substrate pyruvate was in the same range as that of $\mathrm{HFB}_{1}$, and substrate inhibition was observed for pyruvate concentrations in the range of $50-100 \mathrm{mM}$ (Fig. 3). With oxaloacetate as co-substrate, reaction rates were lower, and the $K_{\mathrm{M}}$ for oxaloacetate was $4,150 \mu \mathrm{M}$ (Fig. 3). Addition of PLP enhanced the aminotransferase activity of FumI-HIS, and saturation was reached already at the lowest concentration tested (10 $\mu \mathrm{M}$ PLP) since a further increase in PLP concentration to $20,40,60,80,100,120,140,160,180$, 200,300 , and $400 \mu \mathrm{M}$ in the assay mixture did not result in a further increase in the reaction rate. Without added PLP, FumI-HIS showed about $23 \%$ of the maximum activity.

Addition of $\mathrm{NaCl}$ to the $20 \mathrm{mM}$ Tris- $\mathrm{HCl}(\mathrm{pH}$ 8.0) reaction buffer reduced the $\mathrm{HFB}_{1}$ deamination rate (Fig. 4). When using $100 \mathrm{mM}$ potassium phosphate or TeorellStenhagen buffer, enzyme activity was also lower than in 20-mM Tris- $\mathrm{HCl}$ buffer of the same $\mathrm{pH}$. Nevertheless, Teorell-Stenhagen buffer was used to determine the optimum $\mathrm{pH}$ for enzyme activity, since this buffer can be adjusted to any $\mathrm{pH}$ between 2.0 and 12.0 (Teorell and Stenhagen 1938). Aminotransferase FumI-HIS was active in the range of $\mathrm{pH} 6.5$ to 9.7 and showed a rather sharp optimum at $\mathrm{pH} 8.0$ and 8.5 (Fig. 5a). The enzyme was active over a broad temperature range of $6^{\circ} \mathrm{C}$ to $45^{\circ} \mathrm{C}$ with an optimum for the $30 \mathrm{~min}$ assay at $35^{\circ} \mathrm{C}$ (Fig. 5b). Significant and rapid thermal inactivation was observed at $50^{\circ} \mathrm{C}$, where traces of 2-keto- $\mathrm{HFB}_{1}$ were formed only at the

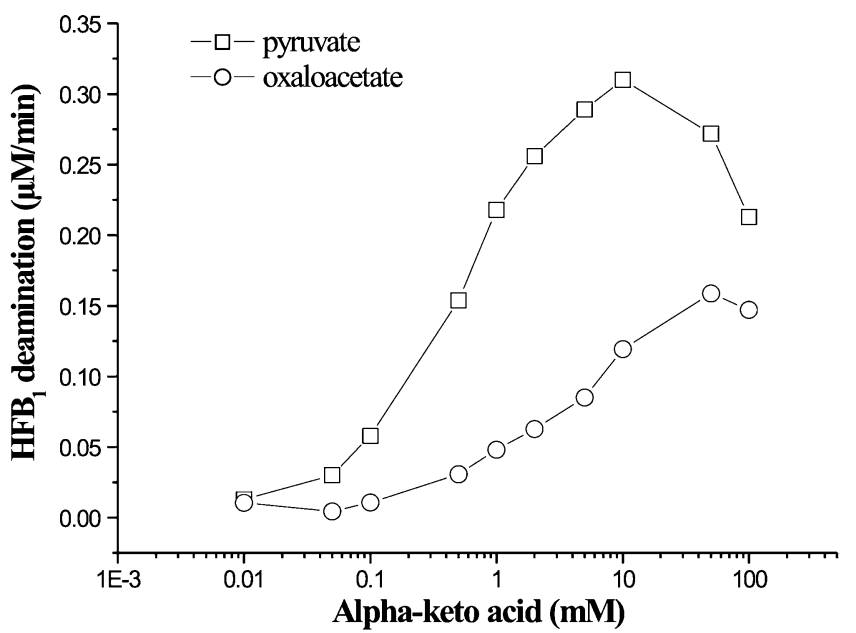

Fig. 3 Correlation between pyruvate concentration or oxaloacetate concentration and $\mathrm{HFB}_{1}$ deamination activity. The reactions were incubated with $94 \mathrm{ng} / \mathrm{ml}$ FumI-HIS and $10 \mu \mathrm{M} \mathrm{HFB}_{1}$ in $20 \mathrm{mM}$ Tris$\mathrm{HCl}(\mathrm{pH} 7.4)$ with $0.1 \mathrm{mg} / \mathrm{ml} \mathrm{BSA}, 20 \mu \mathrm{M}$ PLP, and the indicated concentration of pyruvate or oxaloacetate at $25^{\circ} \mathrm{C}$. Samples were taken and analyzed, and reaction rates were calculated as described in Materials and Methods. The reaction mixtures without co-substrates (negative controls), which are not shown in the semi-logarithmic plot, gave $\mathrm{HFB}_{1}$ deamination rates of zero 


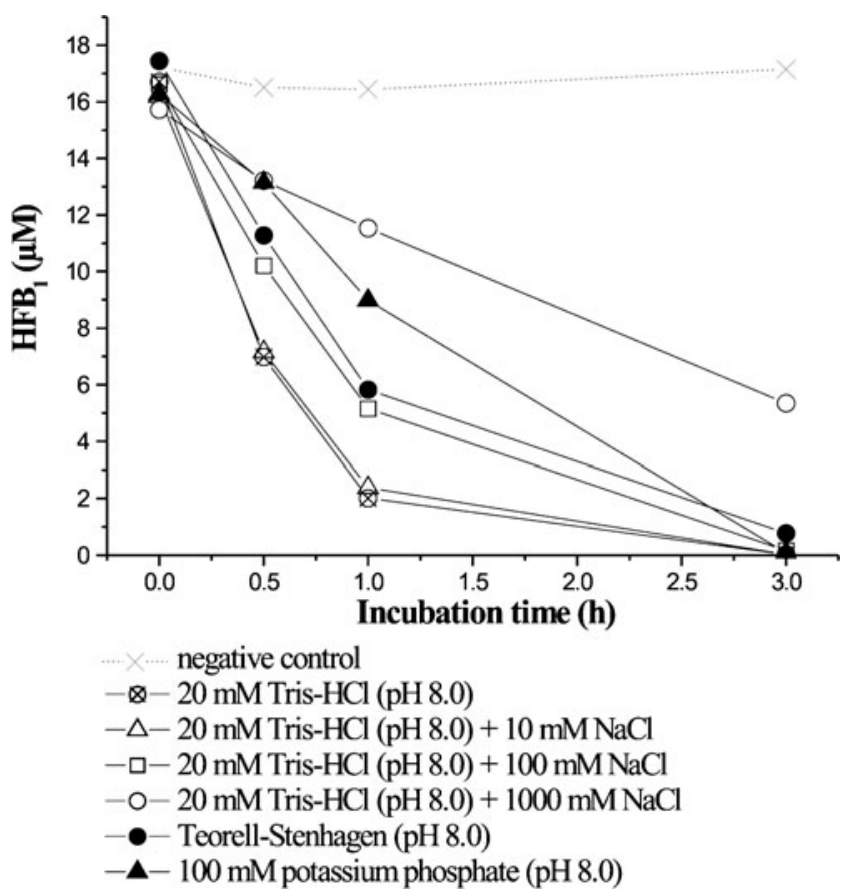

Fig. 4 Effect of different buffers and salt concentrations on the $\mathrm{HFB}_{1}$-deamination rate of aminotransferase FumI-HIS. Negative control: $20 \mathrm{mM}$ Tris- $\mathrm{HCl}$ ( $\mathrm{pH}$ 8.0) with buffer instead of enzyme

beginning of the incubation period (data not shown). Chromatograms of samples from the $\mathrm{HFB}_{1}$ deamination reaction of this experiment at $35^{\circ} \mathrm{C}$ are shown in Fig. 6 . Furthermore, FumI-HIS was incubated with intact $\mathrm{FB}_{1}$ instead of hydrolyzed $\mathrm{FB}_{1}$ under identical conditions, but $\mathrm{FB}_{1}$ was not deaminated. Reaction with a hydrolyzed total fumonisin extract from $F$. verticillioides culture material performed under the same conditions showed that, in addition to $\mathrm{HFB}_{1}, \mathrm{HFB}_{2}$, and $\mathrm{HFB}_{3}$ were substrates of FumI-HIS as well. When FumI-HIS was preincubated at an acidic $\mathrm{pH}$ and $35^{\circ} \mathrm{C}$ for $1 \mathrm{~h}$ before $\mathrm{HFB}_{1}$ deamination was measured, the activity was reduced after incubation at $\mathrm{pH} 6.5$ or less, and completely abolished after incubation at $\mathrm{pH}$ below 4.0 (Fig. 7a). Incubation at $\mathrm{pH} 8.0$ for $1 \mathrm{~h}$ at various temperatures resulted in a steady decrease of FumI activity with increasing temperature, and the enzyme was completely inactivated after incubation at $60^{\circ} \mathrm{C}$. Even after incubation at $7^{\circ} \mathrm{C}$, a $15 \%$ loss of enzyme activity compared to non-preincubated FumI was determined (Fig. 7b).

The apparent steady-state kinetic parameters of FumIHIS catalyzed $\mathrm{HFB}_{1}$ deamination were determined for a saturating co-substrate concentration of $5 \mathrm{mM}$ pyruvate in $20 \mathrm{mM}$ Tris- $\mathrm{HCl}$ buffer $(\mathrm{pH} 8.0)$ at $35^{\circ} \mathrm{C}$, and the Michaelis-Menten plot is shown in Fig. 8. The apparent $V_{\max }$ value of $0.022 \mu \mathrm{M} / \mathrm{min}$ was reached at $5 \mu \mathrm{M} \mathrm{HFB}_{1}$ when $10 \mathrm{ng} / \mathrm{ml}$ of FumI-HIS was present in the reaction mixture. A further increase in substrate $\left(\mathrm{HFB}_{1}\right)$ concentration resulted in a significant reduction of the reaction rate,
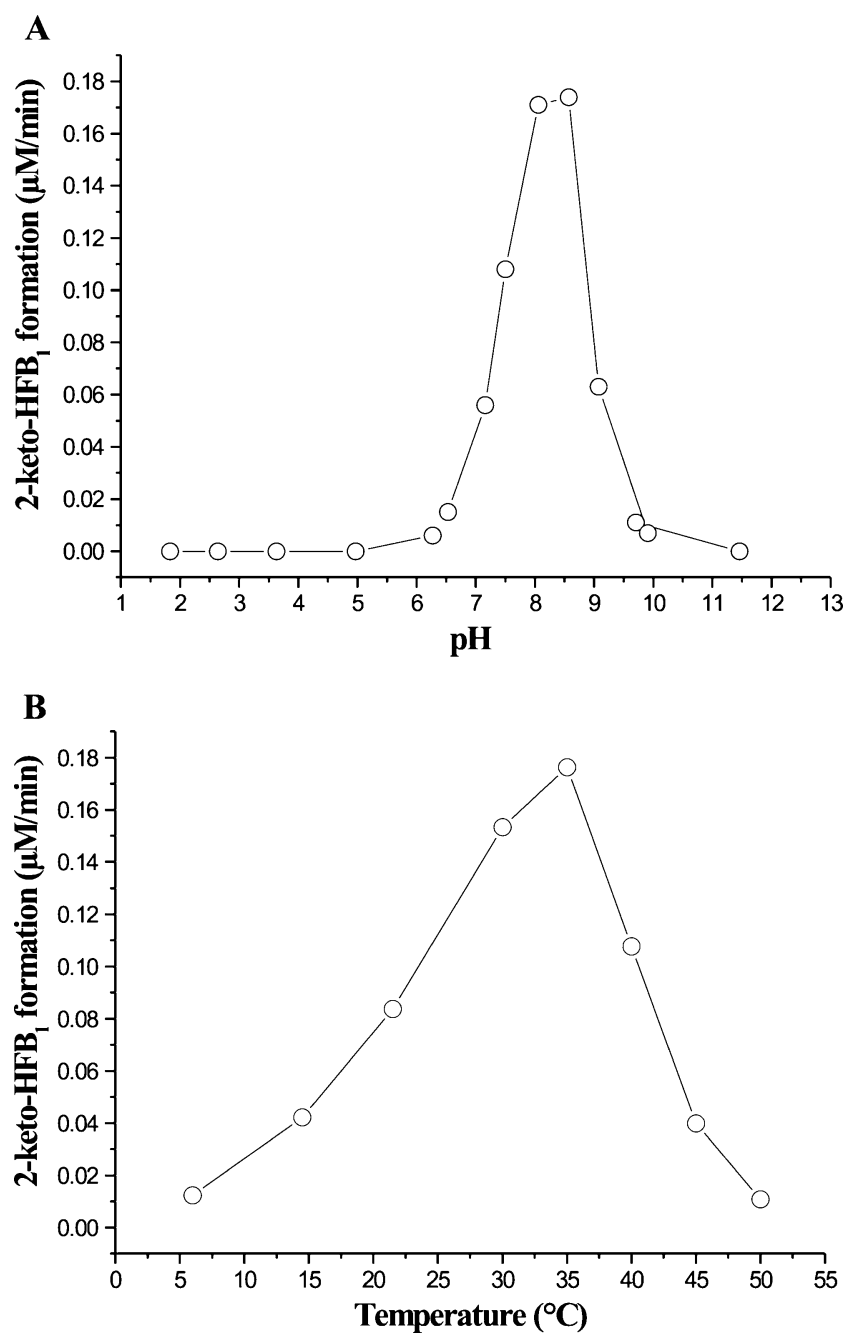

Fig. 5 Determination of optimum $\mathrm{pH}$ (a) and temperature (b) for FumI-HIS activity. The reactions were incubated with $67 \mathrm{ng} / \mathrm{ml} \mathrm{FumI-}$ HIS and $10 \mu \mathrm{M} \mathrm{HFB}$ in Teorell-Stenhagen buffer, with supplements as described in Materials and Methods, set to the indicated $\mathrm{pH}$ values (a) or to $\mathrm{pH} 8.0(\mathbf{b})$, at $25^{\circ} \mathrm{C}$ (a) or the indicated temperatures (b)

indicating substrate inhibition. The $k_{\text {cat }}$ value was calculated to be $104 \mathrm{~min}^{-1}$ using the theoretical molecular mass of FumI-HIS, and the Michaelis constant $K_{\mathrm{M}}$ for $\mathrm{HFB}_{1}$ was determined to be $1.1 \mu \mathrm{M}$. The specific $\mathrm{HFB}_{1}$ deamination activity was $2.2 \mu \mathrm{mol} / \mathrm{min} / \mathrm{mg}$.

Structure determination of the reaction product by NMR

From the $1 \mathrm{D}{ }^{1} \mathrm{H}$ - to ${ }^{13} \mathrm{C}$-APT-NMR spectra, it was obvious that the sample did not contain a single species, but three different forms. In order to analyze the molecular structures of these compounds, ${ }^{1} \mathrm{H}^{1} \mathrm{H}$ COSY, ${ }^{1} \mathrm{H}^{13} \mathrm{C}$ HSQC, and ${ }^{1} \mathrm{H}^{13} \mathrm{C}$ HMBC spectra were recorded. Using these two-dimensional methods, all of the structures could be elucidated unambiguously, and complete assignments of ${ }^{1} \mathrm{H}$ and ${ }^{13} \mathrm{C}$ signals were established (Table 1). Thus, the structures were 
Fig. 6 LC-MS chromatograms of samples from a $\mathrm{HFB}_{1}$ transamination reaction. Samples of $10 \mu \mathrm{M} \mathrm{HFB}_{1}$ in Teorell-Stenhagen buffer $(\mathrm{pH} 8.0)$ at $35^{\circ} \mathrm{C}$ were taken before (a), $30 \mathrm{~min}(\mathbf{b})$, or 240 min (c) after addition of purified aminotransferase FumI-HIS to a final concentration of $67 \mathrm{ng} / \mathrm{ml}$. $\mathrm{HFB}_{1}$ and 2-keto-HFB ${ }_{1}$ were separated on a $\mathrm{C} 8$ reversed phase column in a formate-acetonitrile gradient and detected in SIM mode

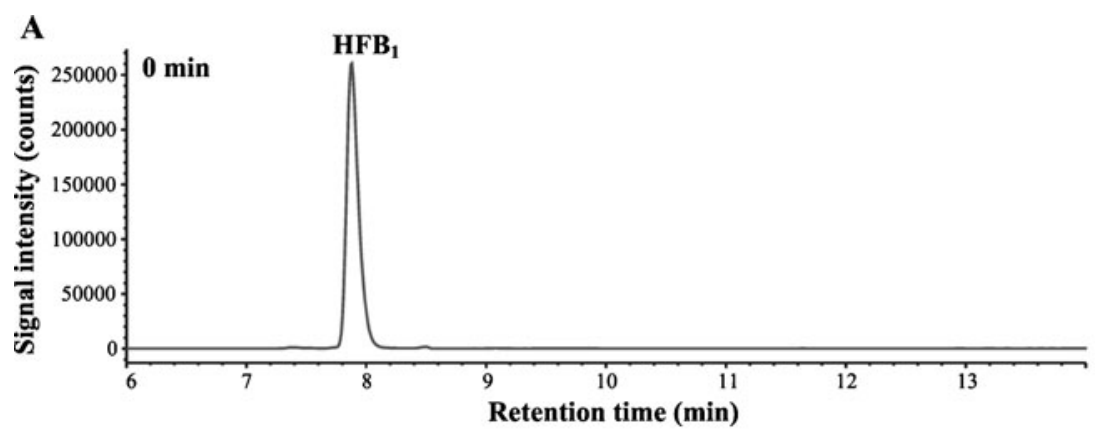

B

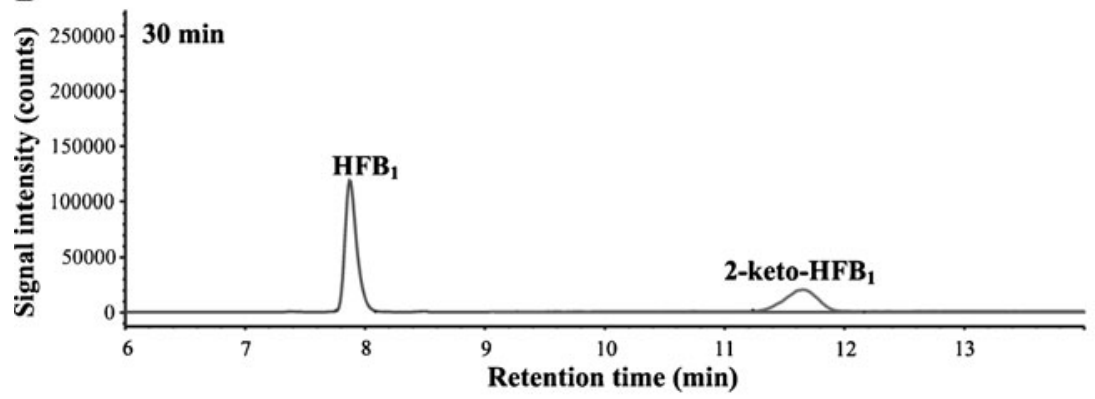

C

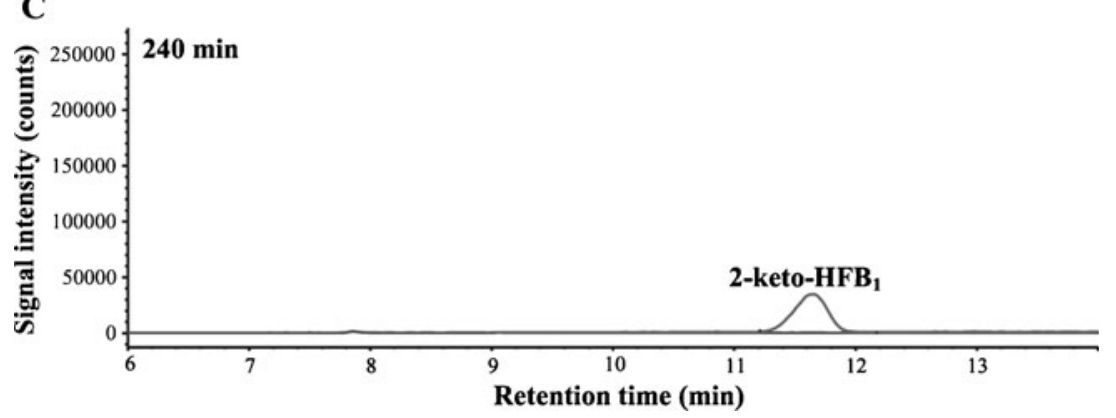

identified as 2-keto-HFB 1 and two cyclic hemiketals formed by ring closure between the 2-keto moiety and the 5-OH. While the hemiketals have already been described (Blackwell et al. 1999), the open-chain keto form has not yet been characterized.

\section{Discussion}

Gastrointestinal detoxification of fumonisins by specific enzymes is a promising concept to ameliorate the effects that fumonisins, which are frequently found as natural contaminants of maize in large parts of the world, have on the health and performance of domestic animals. It is important to know the characteristics of an enzymecatalyzed reaction before a technological application can be considered. We determined some key properties of the aminotransferase FumI of Sphingopyxis sp. MTA144 with respect to its reaction with fumonisins. The enzyme is active with hydrolyzed $\mathrm{FB}_{1}$, the first intermediate in all known pathways of $\mathrm{FB}_{1}$ catabolism, and not with $\mathrm{FB}_{1}$ itself and catalyzes the transfer of the 2-amino group onto a suitable acceptor (Heinl et al. 2010). Since the corresponding amino group of structurally similar sphinganine is acylated by ceramide synthase, which is the molecular target that is inhibited by fumonisins (Wang et al. 1991), the deamination reaction can be considered as important for detoxification of fumonisins. To our knowledge, no reports on the toxicity of 2 -keto-HFB ${ }_{1}$ have been published, and we have not studied its toxicity yet. However, the amino group is thought to play a key role for the toxicity of $\mathrm{FB}_{1}$ (Gelderblom et al. 1993; Lu et al. 1997; Norred et al. 2001; Fernandez-Surumay et al. 2004), and obviously, 2-keto-HFB ${ }_{1}$ cannot be acylated in a similar way as $\mathrm{HFB}_{1}$ (Humpf et al. 1998; Seiferlein et al. 2007). Therefore, it seems reasonable to speculate that 2 -keto-HFB may be non-toxic.

Numerous aminotransferases have been identified and studied since the first description of this class of enzymes (Needham 1930), and several are used in industrial applications for the production of a range of natural and non-natural amino acids and amines (Taylor et al. 1998; 

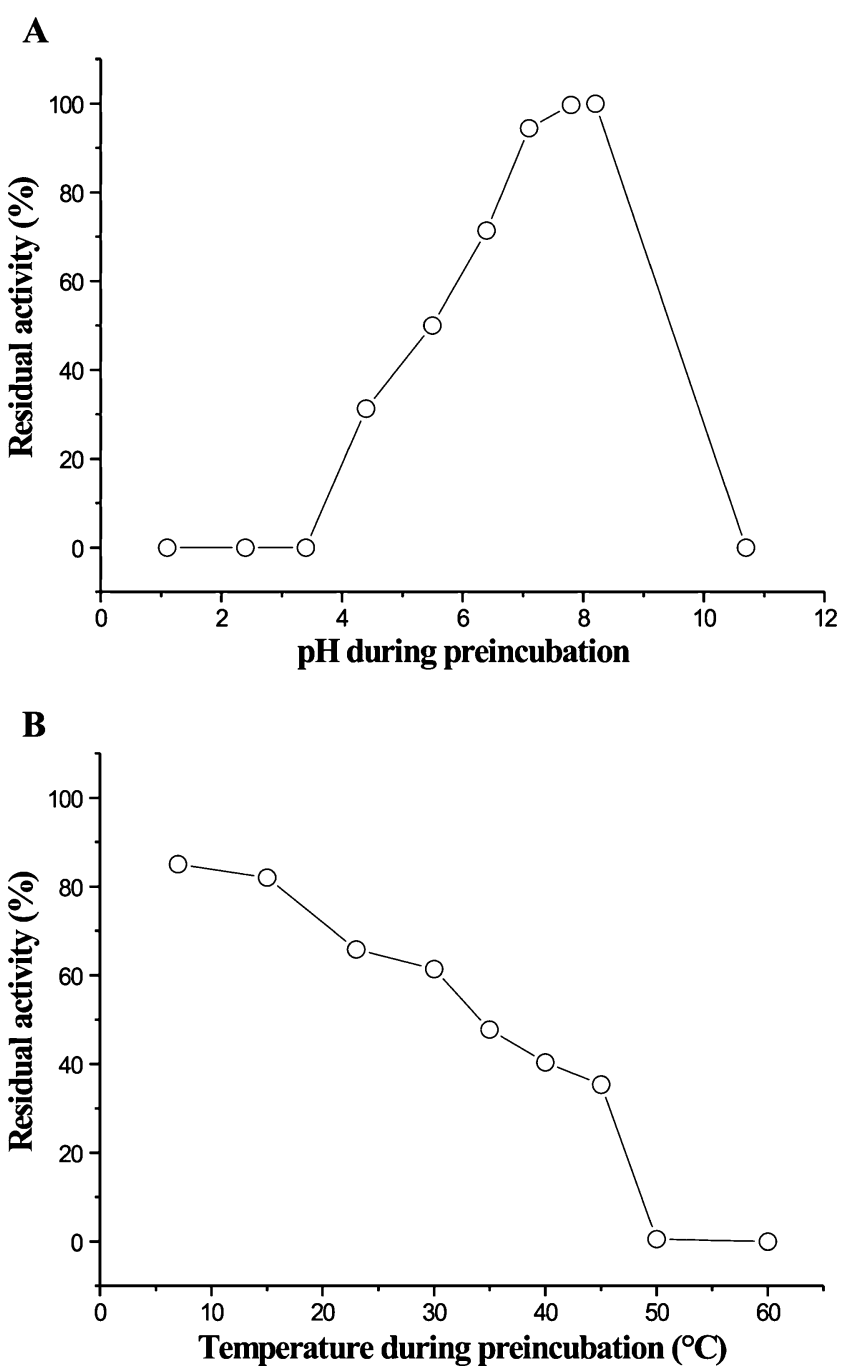

Fig. 7 Stability of FumI-HIS at various $\mathrm{pH}$ values (a) and temperatures (b). Fourteen micrograms per milliliter FumI-HIS was incubated in Teorell-Stenhagen buffer at the indicated $\mathrm{pH}$ at $35^{\circ} \mathrm{C}$ (a) or in the same buffer at $\mathrm{pH} 8.0$ at the indicated temperature (b) for $1 \mathrm{~h}$. Residual enzyme activity was determined as described in Materials and Methods. The measured activities after incubation at $\mathrm{pH} 8.0$ (a) or without preincubation (b) were set to $100 \%$

Hwang et al. 2005; Zhu and Hua 2009). However, this is the first characterization of an aminotransferase that catalyzes deamination of a fumonisin. Our work may lead to the further expansion of the range of aminotransferase applications to mycotoxin detoxification. Since $\mathrm{FB}_{1}$ is not a substrate for FumI, a possible technological application of the enzyme will require its combined use together with a fumonisin carboxylesterase such as FumD, so that $\mathrm{HFB}_{1}$, the substrate of FumI, is generated by hydrolytic cleavage of the two tricarballylic acid side chains of $\mathrm{FB}_{1}$. In this respect, the substrate specificity of FumI is quite remarkable, since the direct vicinity of the 2-amino group is identical in $\mathrm{FB}_{1}$ and $\mathrm{HFB}_{1}$ (Fig. 1). Since $\mathrm{HFB}_{2}$ and $\mathrm{HFB}_{3}$

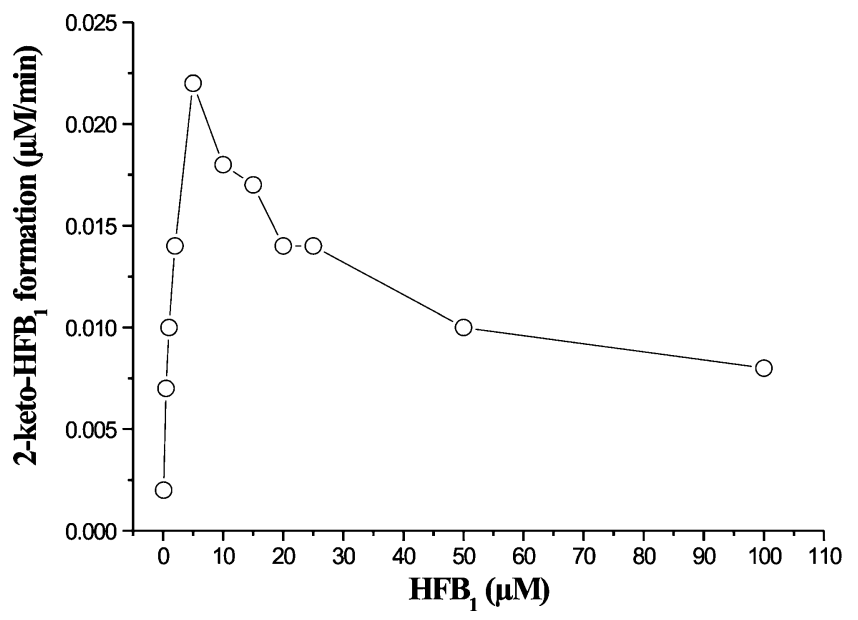

Fig. 8 Initial $\mathrm{HFB}_{1}$ deamination reaction rate as a function of substrate concentration. The reactions were performed with $10 \mathrm{ng} / \mathrm{ml}$ FumI-HIS and $5 \mathrm{mM}$ pyruvate, a saturating co-substrate concentra-

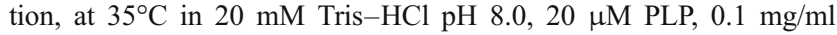
BSA. $\mathrm{HFB}_{1}$ concentrations ranged from 0.1 to $100 \mu \mathrm{M}$

are also deaminated by the enzyme, the 10-hydroxyl and 5-hydroxyl groups of $\mathrm{HFB}_{1}$, which are lacking in $\mathrm{HFB}_{2}$ and $\mathrm{HFB}_{3}$, respectively, are apparently not essential for substrate recognition. The ability of FumI to use several different $\alpha$-keto acids as amino group acceptors is also noteworthy. Even though pyruvate was the preferred co-substrate when various $\alpha$-keto acids were tested at the identical molar concentrations in our study, it is tempting to speculate that the relaxed co-substrate specificity of FumI may have biological significance for its function in Sphingopyxis sp. MTA144. Depending on the available $\alpha$-keto acids, FumI could thus produce alanine from pyruvate, aspartate from oxaloacetate, or glycine from glyoxylate in vivo. The affinity of FumI for its co-substrate (Fig. 3), which is much lower than the affinity for $\mathrm{HFB}_{1}$ (Fig. 8) when judged by the $K_{\mathrm{M}}$ values, may also be important for the enzyme in vivo, since the compatible $\alpha$-keto acids are also intermediates in energy metabolism. In this context, it is interesting to note that the fum gene cluster of Sphingopyxis sp. MTA144 encodes three genes, the tricarballylate proton symport pump FumG, the tricarballylate dehydrogenase FumE, and the citrate utilization protein B FumF, which supposedly allow utilization of the two tricarballylic acid side chains of $\mathrm{FB}_{1}$ and their conversion to citric acid (Heinl et al. 2010). Oxaloacetate and glyoxylate, which both accept the amino group during the FumI-catalyzed reaction, can both be generated from citric acid in the Krebs cycle or the glyoxylate cycle. For a technological application of FumI, this co-substrate requirement together with the comparatively low $K_{\mathrm{M}}$ value implies that pyruvate or one of the other suitable $\alpha$-keto acids will have to be present or will have to be provided together with the enzyme at 
Table $1{ }^{1} \mathrm{H}$ and ${ }^{13} \mathrm{C}$ NMR assignment of 2-keto-HFB ${ }_{1}$ and its hemiketal forms (1999)

\begin{tabular}{|c|c|c|c|c|c|c|}
\hline & \multicolumn{2}{|c|}{ 2-Keto-HFB 1} & \multicolumn{2}{|c|}{$\alpha$-Hemiketal ${ }^{\mathrm{a}}$} & \multicolumn{2}{|c|}{$\beta$-Hemiketal ${ }^{\mathrm{a}}$} \\
\hline & ${ }^{1} \mathrm{H}$ & ${ }^{13} \mathrm{C}$ & ${ }^{1} \mathrm{H}$ & ${ }^{13} \mathrm{C}$ & ${ }^{1} \mathrm{H}$ & ${ }^{13} \mathrm{C}$ \\
\hline 1 & 2.14 & 25.8 & 1.32 & 22.8 & 1.29 & 25.0 \\
\hline 2 & - & 212.4 & - & 106.9 & - & 102.2 \\
\hline 3 & 4.28 & 75.7 & 3.87 & 78.2 & 3.80 & 76.8 \\
\hline 4 & $1.72,1.50$ & 41.4 & $2.40,1.35$ & 40.5 & $2.23,1.52$ & 38.9 \\
\hline 5 & 3.70 & 68.7 & 3.97 & 77.0 & 3.80 & 76.1 \\
\hline 6 & $1.50-1.40$ & 38.8 & $1.58,1.44$ & 37.4 & $1.45-1.40$ & 38.5 \\
\hline 7 & $1.45-1.25$ & $\approx 27$ & $1.45-1.25$ & $\approx 27$ & $1.45-1.25$ & $\approx 27$ \\
\hline 8 & $1.45-1.25$ & $\approx 27$ & $1.45-1.25$ & $\approx 27$ & $1.45-1.25$ & $\approx 27$ \\
\hline 9 & $1.40-1.35$ & 39.4 & $1.40-1.35$ & 39.4 & $1.40-1.35$ & 39.4 \\
\hline 10 & 3.59 & 69.8 & 3.59 & 69.8 & 3.59 & 69.8 \\
\hline 11 & $1.48,1.06$ & 44.4 & $1.48,1.06$ & 44.4 & $1.48,1.06$ & 44.4 \\
\hline 12 & 1.87 & 26.9 & 1.87 & 26.9 & 1.87 & 26.9 \\
\hline 12-Me & 0.94 & 21.7 & 0.94 & 21.7 & 0.94 & 21.7 \\
\hline 13 & $1.40-1.25$ & 40.1 & $1.40-1.25$ & 40.1 & $1.40-1.25$ & 40.1 \\
\hline 14 & 3.61 & 70.2 & 3.61 & 70.2 & 3.61 & 70.2 \\
\hline 15 & 3.16 & 80.2 & 3.16 & 80.2 & 3.16 & 80.2 \\
\hline 16 & 1.55 & 35.6 & 1.55 & 35.6 & 1.55 & 35.6 \\
\hline $16-\mathrm{Me}$ & 0.84 & 16.4 & 0.84 & 16.4 & 0.84 & 16.4 \\
\hline 17 & $1.61,1.20$ & 32.2 & $1.61,1.20$ & 32.2 & $1.61,1.20$ & 32.2 \\
\hline 18 & $1.36,1.20$ & 30.0 & $1.36,1.20$ & 30.0 & $1.36,1.20$ & 30.0 \\
\hline 19 & $1.25-1.35$ & 23.9 & $1.25-1.35$ & 23.9 & $1.25-1.35$ & 23.9 \\
\hline 20 & 0.90 & 14.5 & 0.90 & 14.5 & 0.90 & 14.5 \\
\hline
\end{tabular}

millimolar concentration to enable efficient and fast $\mathrm{HFB}_{1}$ deamination. However, if the enzyme is to be used for gastrointestinal $\mathrm{HFB}_{1}$ deamination, this co-substrate requirement might be covered to some extent by the presence of $\alpha$-keto acids in the chymus. It cannot be excluded that other amino group acceptors that we have not yet identified may enable higher reaction rates even at low concentration.

Blackwell et al. have noted before that 2-keto-HFB 1 can undergo cyclization between the 5-hydroxyl group and $\mathrm{C}-2$ of 2-keto-HFB $\mathrm{H}_{1}$ to form two isomers of a hemiketal, and that this reaction is favored by the presence of methanol in the solvent (Blackwell et al. 1999). We made the same observation and adapted our procedure for purification and NMR characterization of 2-keto-HFB ${ }_{1}$ to work without methanol. Nevertheless, the NMR characterization showed that our preparation of 2 -keto-HFB 1 was not pure, and the signals indicative of the hemiketals were still present. As the C-1-C-5 part of 2-keto-HFB 1 resembles a simplified ketose structure, an equilibrium between the open-chain and cyclized forms may be the explanation for this behavior since in carbohydrate chemistry, such equilibria are ubiquitous. This may also be one reason that the 2-keto-HFB peaks that eluted from a C8 HPLC column were broader than the $\mathrm{HFB}_{1}$ peaks.
Overexpression of FumI in E. coli and the subsequent purification procedure (Hartinger et al. 2010) result in enzyme preparations that apparently are not saturated with the prosthetic group PLP, as can be concluded from the finding that addition of PLP to such an enzyme preparation enhances activity. Aminotransferases were reported to occur as mixtures of their apo- and holo-forms also when isolated from their natural environment (Moss 1976). Increasing the PLP concentrations above $10 \mu \mathrm{m}$ in the reconstitution experiments of recombinant FumI-HIS showed no further increase of aminotransferase activity, which is consistent with the tight binding of PLP that has been reported for other aminotransferases (Ford et al. 1980; Eliot and Kirsch 2004). If batches of enzyme need to be prepared for technological application in the future, they can be saturated with low concentrations of PLP before their application to ensure that FumI is predominantly available as a holoenzyme.

FumI-HIS displayed $\mathrm{HFB}_{1}$ deamination activity in all buffers we tested, and these covered a wide range of salt concentrations (Fig. 4). This indicates that the proposed application of FumI is unlikely to be limited by buffer salt requirements. The lack of enzyme activity at acidic $\mathrm{pH}$ (Fig. 5a) rules out that FumI is already active in the stomach when provided as an animal feed supplement. 
However, FumI can be expected to function in sections of the upper intestine where the $\mathrm{pH}$ is close to neutral or even slightly higher. The temperature optimum of $35^{\circ} \mathrm{C}$ and good activity at $40^{\circ} \mathrm{C}$ found for FumI-HIS (Fig. 5b) imply that the actual body temperature of animals, which e.g. was reported to be $38.8^{\circ} \mathrm{C}$ for piglets (Ingram and Legge 1970), should be well suited for high enzyme activity. Based on our determination of $\mathrm{pH}$ stability (Fig. 7a), it will be necessary to provide FumI in a formulation that enables shuttling through the stomach without inactivation at low $\mathrm{pH}$. Simultaneously, the enzyme could thus be protected from proteolytic degradation. Technologies for microencapsulation and targeted release in the intestine have previously been developed (Champagne and Fustier 2007).

We were surprised to see a reduction of $\mathrm{HFB}_{1}$ deamination activity after preincubation of FumI-HIS at $7^{\circ} \mathrm{C}$, because we had observed that a preparation of enzyme that was stored in the fridge apparently retained full activity over several weeks. Maybe handling of the enzyme at low concentration contributed to the observed loss of activity. Likewise, the maximal specific reaction rate measured in the experiment shown in Fig. 8, using $10 \mathrm{ng} / \mathrm{ml}$ FumI-HIS, was lower than in the experiment shown in Fig. 3, when $94 \mathrm{ng} / \mathrm{ml}$ FumI-HIS was used.

The $K_{\mathrm{M}}$ value we determined for $\mathrm{HFB}_{1}$ deamination, $1.1 \mu \mathrm{M}$, corresponds to $0.794 \mathrm{mg} / \mathrm{kg} \mathrm{FB}_{1}$. Since the fumonisin concentrations frequently found in maize (Binder et al. 2007; Gonzalez Pereyra et al. 2008; Gong et al. 2009; Monbaliu et al. 2010) and known to have toxic effects on animals (Ross et al. 1991; Taranu et al. 2005) are higher, FumI should have sufficient affinity for the substrate HFB to enable detoxification in the range of fumonisin concentrations that are relevant in agriculture. The decrease of FumI activity observed at $\mathrm{HFB}_{1}$ concentrations higher than $10 \mu \mathrm{M}$, which is equivalent to $7.22 \mathrm{mg} / \mathrm{FB}_{1}$, can be interpreted as substrate inhibition. Since the guidance value for the maximum acceptable concentration of $\mathrm{FB}_{1}$ and $\mathrm{FB}_{2}$ in e.g. pig feed is $5 \mathrm{mg} / \mathrm{kg}$ according to the European Commission Recommendation 2006/576/EC, this observed inhibition of activity at higher $\mathrm{HFB}_{1}$ concentrations may not be relevant from a technological point of view. In case enzymatic detoxification by a combination of FumD and FumI of a highly contaminated commodity is required, substrate inhibition of FumI may be avoided by adapting FumD activity to that of FumI, so that the $\mathrm{HFB}_{1}$ is continuously formed in sub-inhibitory concentrations.

Feed enzymes may be useful for the degradation of antinutritive substances that are naturally contained in agricultural commodities, or to enhance the nutritional value of feed. The use of phytase as a feed enzyme to release phosphate from phytate that is naturally contained in plant material is well established (Lei and Porres 2003;
Rao et al. 2009). Based on the enzyme characteristics reported here, FumI may also be suitable for future applications as a feed enzyme to enhance the salubriousness of maize that is naturally contaminated with fumonisins, if the specific properties and requirements of FumI are considered in this application.

Acknowledgments We would like to thank Markus Kainz and Elisabeth Pichler from Quantas Analytics GmbH (Tulln, Austria) for collaboration on LC-MS analysis, and Patricia Fajtl for support with making preparations of FumI-HIS. This work was supported in part by the Austrian Research Promotion Agency FFG and the Christian Doppler Research Association.

Conflict of interest The authors declare no conflict of interest.

Open Access This article is distributed under the terms of the Creative Commons Attribution Noncommercial License which permits any noncommercial use, distribution, and reproduction in any medium, provided the original author(s) and source are credited.

\section{References}

Abel S, Gelderblom WCA (1998) Oxidative damage and fumonisin $\mathrm{B}_{1}$-induced toxicity in primary rat hepatocytes and rat liver in vivo. Toxicology 131:121-131

Bezuidenhout SC, Gelderblom WCA, Gorst-Allman CP, Horak RM, Marasas WFO, Spiteller G, Vleggaar R (1988) Structure elucidation of the fumonisins, mycotoxins from Fusarium moniliforme. J Chem Soc, Chem Commun 743-745

Binder EM, Tan LM, Chin LJ, Handl J, Richard J (2007) Worldwide occurrence of mycotoxins in commodities, feeds and feed ingredients. Anim Feed Sci Technol 137:265-282

Blackwell BA, Gilliam JT, Savard ME, Miller JD, Duvick JP (1999) Oxidative deamination of hydrolyzed fumonisin $\mathrm{B}_{1}\left(\mathrm{AP}_{1}\right)$ by cultures of Exophiala spinifera. Nat Toxins 7:31-38

Champagne CP, Fustier P (2007) Microencapsulation for the improved delivery of bioactive compounds into foods. Curr Opin Biotechnol 18:184-190

Chen J, Mirocha CJ, Xie W, Hogge L, Olson D (1992) Production of the mycotoxin fumonisin $\mathrm{B}_{1}$ by Alternaria alternata f. sp. lycopersici. Appl Environ Microbiol 58:3928-3931

Duvick JP, Maddox JR, Gilliam, JT (2003) Compositions and methods for fumonisin detoxification. US Patent 6538177, Pioneer Hi-Bred International

Eliot AC, Kirsch JF (2004) Pyridoxal phosphate enzymes: mechanistic, structural, and evolutionary considerations. Annu Rev Biochem 73:383-415

Fernandez-Surumay G, Osweiler GD, Yaeger MJ, Hauck CC, Hendrich S, Murphy PA (2004) Glucose reaction with fumonisin $\mathrm{B}_{1}$ partially reduces its toxicity in swine. J Agric Food Chem 52:7732-7739

Flynn TJ, Stack ME, Troy AL, Chirtel SJ (1997) Assessment of the embryotoxic potential of the total hydrolysis product of fumoni$\sin \mathrm{B}_{1}$ using cultured organogenesis-staged rat embryos. Food Chem Toxicol 35:1135-1141

Ford GC, Eichele G, Jansonius JN (1980) Three-dimensional structure of a pyridoxal-phosphate-dependent enzyme, mitochondrial aspartate aminotransferase. Proc Natl Acad Sci USA 77:25592563 
Frisvad JC, Smedsgaard J, Samson RA, Larsen TO, Thrane U (2007) Fumonisin $\mathrm{B}_{2}$ production by Aspergillus niger. J Agric Food Chem 55:9727-9732

Gelderblom WCA, Abel S, Smuts CM, Marnewick J, Marasas WF, Lemmer ER, Ramljak D (2001) Fumonisin-induced hepatocarcinogenesis: mechanisms related to cancer initiation and promotion. Environ Health Perspect 109(Suppl 2):291-300

Gelderblom WCA, Cawood ME, Snyman SD, Vleggaar R, Marasas WF (1993) Structure-activity relationships of fumonisins in short-term carcinogenesis and cytotoxicity assays. Food Chem Toxicol 31:407-414

Gelderblom WCA, Jaskiewicz K, Marasas WF, Thiel PG, Horak RM, Vleggaar R, Kriek NP (1988) Fumonisins-novel mycotoxins with cancer-promoting activity produced by Fusarium moniliforme. Appl Environ Microbiol 54:1806-1811

Gelderblom WCA, Kriek NP, Marasas WF, Thiel PG (1991) Toxicity and carcinogenicity of the Fusarium moniliforme metabolite, fumonisin $\mathrm{B}_{1}$, in rats. Carcinogenesis 12:1247-1251

Gelineau-van Waes J, Starr L, Maddox J, Aleman F, Voss KA, Wilberding J, Riley RT (2005) Maternal fumonisin exposure and risk for neural tube defects: mechanisms in an in vivo mouse model. Birth Defects Res A Clin Mol Teratol 73:487-497

Gong HZ, Ji R, Li YX, Zhang HY, Li B, Zhao Y, Sun L, Yu F, Yang J (2009) Occurrence of fumonisin $B_{1}$ in corn from the main cornproducing areas of China. Mycopathologia 167:31-36

Gonzalez Pereyra ML, Pereyra CM, Ramirez ML, Rosa CA, Dalcero AM, Cavaglieri LR (2008) Determination of mycobiota and mycotoxins in pig feed in central Argentina. Lett Appl Microbiol 46:555-561

Harrison LR, Colvin BM, Greene JT, Newman LE, Cole JR (1990) Pulmonary edema and hydrothorax in swine produced by fumonisin $\mathrm{B}_{1}$, a toxic metabolite of Fusarium moniliforme. J Vet Diagn Invest 2:217-221

Hartinger D, Heinl S, Schwartz HE, Grabherr R, Schatzmayr G, Haltrich D, Moll WD (2010) Enhancement of solubility in Escherichia coli and purification of an aminotransferase from Sphingopyxis sp. MTA144 for deamination of hydrolyzed fumonisin $B_{1}$. Microb Cell Fact 9:62

Haschek WM, Gumprecht LA, Smith G, Tumbleson ME, Constable PD (2001) Fumonisin toxicosis in swine: an overview of porcine pulmonary edema and current perspectives. Environ Health Perspect 109(Suppl 2):251-257

Heinl S, Hartinger D, Thamhesl M, Schatzmayr G, Moll WD, Grabherr R (2011) An aminotransferase from bacterium ATCC 55552 deaminates hydrolyzed fumonisin $\mathrm{B}_{1}$. Biodegradation 22: $25-30$

Heinl S, Hartinger D, Thamhesl M, Vekiru E, Krska R, Schatzmayr G, Moll WD, Grabherr R (2010) Degradation of fumonisin $B_{1}$ by the consecutive action of two bacterial enzymes. J Biotechnol 145:120-129

Hendrich S, Miller KA, Wilson TM, Murphy PA (1993) Toxicity of Fusarium proliferatum fermented nixtamalized corn-based diets feed to rats: effect of nutritional status. J Agric Food Chem 41:1649-1654

Howard PC, Couch LH, Patton RE, Eppley RM, Doerge DR, Churchwell MI, Marques MM, Okerberg CV (2002) Comparison of the toxicity of several fumonisin derivatives in a 28-day feeding study with female $\mathrm{B} 6 \mathrm{C}_{3} \mathrm{~F}_{1}$ mice. Toxicol Appl Pharmacol 185:153-165

Humpf HU, Schmelz EM, Meredith FI, Vesper H, Vales TR, Wang E, Menaldino DS, Liotta DC, Merrill AH (1998) Acylation of naturally occurring and synthetic 1-deoxysphinganines by ceramide synthase. Formation of N-palmitoyl-aminopentol produces a toxic metabolite of hydrolyzed fumonisin, $\mathrm{AP}_{1}$, and a new category of ceramide synthase inhibitor. J Biol Chem 273:1906019064
Hwang BY, Cho BK, Yun H, Koteshwar K, Kim BG (2005) Revisit of aminotransferase in the genomic era and its application to biocatalysis. J Mol Catal B Enzym 37:47-55

Ingram DL, Legge KF (1970) Variations in deep body temperature in the young unrestrained pig over the $24 \mathrm{~h}$ period. J Physiol 210:989-998

Karlovsky P (1999) Biological detoxification of fungal toxins and its use in plant breeding, feed and food production. Nat Toxins 7:123

Kellerman TS, Marasas WF, Thiel PG, Gelderblom WCA, Cawood M, Coetzer JA (1990) Leukoencephalomalacia in two horses induced by oral dosing of fumonisin $\mathrm{B}_{1}$. Onderstepoort $\mathrm{J}$ Vet Res 57:269-275

Lei XG, Porres JM (2003) Phytase enzymology, applications, and biotechnology. Biotechnol Lett 25:1787-1794

Lu Z, Dantzer WR, Hopmans EC, Prisk V, Cunnick JE, Murphy PA, Hendrich S (1997) Reaction with fructose detoxifies fumonisin $\mathrm{B}_{1}$ while stimulating liver-associated natural killer cell activity in rats. J Agric Food Chem 45:803-809

Marasas WF (2001) Discovery and occurrence of the fumonisins: a historical perspective. Environ Health Perspect 109(Suppl 2):239-243

Marasas WF, Kellerman TS, Gelderblom WCA, Coetzer JA, Thiel PG, van der Lugt JJ (1988) Leukoencephalomalacia in a horse induced by fumonisin $\mathrm{B}_{1}$ isolated from Fusarium moniliforme. Onderstepoort J Vet Res 55:197-203

Merrill AH, Sullards MC, Wang E, Voss KA, Riley RT (2001) Sphingolipid metabolism: roles in signal transduction and disruption by fumonisins. Environ Health Perspect 109(Suppl 2):283-289

Mogensen JM, Moller KA, von Freiesleben P, Labuda R, Varga E, Sulyok M, Kubatova A, Thrane U, Andersen B, Nielsen KF (2011) Production of fumonisins $\mathrm{B}_{2}$ and $\mathrm{B}_{4}$ in Tolypocladium species. J Ind Microbiol Biotechnol. doi:10.1007/s10295-0100916-1 (in press)

Monbaliu S, Van Poucke C, Detavernier C, Dumoulin F, Van De Velde M, Schoeters E, Van Dyck S, Averkieva O, Van Peteghem C, De Saeger S (2010) Occurrence of mycotoxins in feed as analyzed by a multi-mycotoxin LC-MS/MS method. J Agric Food Chem 58:66-71

Moss DW (1976) Reactivation of the apoenzyme of aspartate aminotransferase in serum. Clin Chim Acta 67:169-174

Needham DM (1930) A quantitative study of succinic acid in muscle: glutamic and aspartic acids as precursors. Biochem J 24:208-227

Norred WP, Riley RT, Meredith FI, Poling SM, Plattner RD (2001) Instability of $\mathrm{N}$-acetylated fumonisin $\mathrm{B}_{1}\left(\mathrm{FA}_{1}\right)$ and the impact on inhibition of ceramide synthase in rat liver slices. Food Chem Toxicol 39:1071-1078

Norred WP, Plattner RD, Dombrink-Kurtzman MA, Meredith FI, Riley RT (1997) Mycotoxin-induced elevation of free sphingoid bases in precision-cut rat liver slices: specificity of the response and structure-activity relationships. Toxicol Appl Pharmacol 147:63-70

Rao DE, Rao KV, Reddy TP, Reddy VD (2009) Molecular characterization, physicochemical properties, known and potential applications of phytases: an overview. Crit Rev Biotechnol 29:182-198

Rheeder JP, Marasas WF, Vismer HF (2002) Production of fumonisin analogs by Fusarium species. Appl Environ Microbiol 68:21012105

Riley RT, Enongene E, Voss KA, Norred WP, Meredith FI, Sharma RP, Spitsbergen J, Williams DE, Carlson DB, Merrill AH (2001) Sphingolipid perturbations as mechanisms for fumonisin carcinogenesis. Environ Health Perspect 109(Suppl 2):301-308

Ross PF, Rice LG, Plattner RD, Osweiler GD, Wilson TM, Owens DL, Nelson HA, Richard JL (1991) Concentrations of fumonisin 
$\mathrm{B}_{1}$ in feeds associated with animal health problems. Mycopathologia 114:129-135

Sadler TW, Merrill AH, Stevens VL, Sullards MC, Wang E, Wang P (2002) Prevention of fumonisin $B_{1}$-induced neural tube defects by folic acid. Teratology 66:169-176

Schmelz EM, Dombrink-Kurtzman MA, Roberts PC, Kozutsumi Y, Kawasaki T, Merrill AH (1998) Induction of apoptosis by fumonisin $B_{1}$ in HT29 cells is mediated by the accumulation of endogenous free sphingoid bases. Toxicol Appl Pharmacol 148:252-260

Seefelder W, Humpf H-U, Schwerdt G, Freudinger R, Gekle M (2003) Induction of apoptosis in cultured human proximal tubule cells by fumonisins and fumonisin metabolites. Toxicol Appl Pharmacol 192:146-153

Seiferlein M, Humpf HU, Voss KA, Sullards MC, Allegood JC, Wang E, Merrill AH (2007) Hydrolyzed fumonisins $\mathrm{HFB}_{1}$ and $\mathrm{HFB}_{2}$ are acylated in vitro and in vivo by ceramide synthase to form cytotoxic N-acyl-metabolites. Mol Nutr Food Res $51: 1120-1130$

Taranu I, Marin DE, Bouhet S, Pascale F, Bailly JD, Miller JD, Pinton P, Oswald IP (2005) Mycotoxin fumonisin $B_{1}$ alters the cytokine profile and decreases the vaccinal antibody titer in pigs. Toxicol Sci 84:301-307

Taylor PP, Pantaleone DP, Senkpeil RF, Fotheringham IG (1998) Novel biosynthetic approaches to the production of unnatural amino acids using transaminases. Trends Biotechnol 16:412-418

Teorell T, Stenhagen E (1938) Ein Universalpuffer für den $\mathrm{pH}-$ Bereich 2.0 bis 12.0. Biochem Z 299:416-419 van der Westhuizen L, Shephard GS, Snyman SD, Abel S, Swanevelder S, Gelderblom WCA (1998) Inhibition of sphingolipid biosynthesis in rat primary hepatocyte cultures by fumonisin $\mathrm{B}_{1}$ and other structurally related compounds. Food Chem Toxicol 36:497-503

Voss KA, Bacon CW, Meredith FI, Norred WP (1996) Comparative subchronic toxicity studies of nixtamalized and water-extracted Fusarium moniliforme culture material. Food Chem Toxicol 34:623-632

Voss KA, Riley RT, Snook ME, Waes JG (2009) Reproductive and sphingolipid metabolic effects of fumonisin $B_{1}$ and its alkaline hydrolysis product in $\mathrm{LM} / \mathrm{Bc}$ mice: hydrolyzed fumonisin $\mathrm{B}_{1}$ did not cause neural tube defects. Toxicol Sci 112:459-467

Voss KA, Smith GW, Haschek WM (2007) Fumonisins: toxicokinetics, mechanism of action and toxicity. Anim Feed Sci Technol 137:299-325

Wattenberg EV, Badria FA, Shier WT (1996) Activation of mitogenactivated protein kinase by the carcinogenic mycotoxin fumoni$\sin \mathrm{B}_{1}$. Biochem Biophys Res Commun 227:622-627

Wang E, Norred WP, Bacon CW, Riley RT, Merrill AH (1991) Inhibition of sphingolipid biosynthesis by fumonisins. Implications for diseases associated with Fusarium moniliforme. J Biol Chem 266:14486-14490

Wild CP, Gong YY (2010) Mycotoxins and human disease: a largely ignored global health issue. Carcinogenesis $31: 71-82$

Zhu D, Hua L (2009) Biocatalytic asymmetric amination of carbonyl functional groups - a synthetic biology approach to organic chemistry. Biotechnol J 4:1420-1431 